\title{
Confinement Model for FRP Confined Normal- and High-Strength Concrete Circular Columns
}

\author{
Thong M. Pham S.M.ASCE ${ }^{1}$; Muhammad N.S. Hadi, M.ASCE ${ }^{2}$
}

\begin{abstract}
A confinement model for FRP confined normal- and high-strength concrete circular columns is established in this study. In addition to the column parameters used in existing models, a new parameter is added for estimating the compressive strength of FRP confined concrete. The proposed model is able to predict the ultimate condition of FRP confined concrete columns that have similar unconfined concrete strength and confining pressure but significant differences in the jacket stiffness. The proposed model was then verified using a database of 574 FRP confined concrete circular columns with different types of FRP. This database covers unconfined concrete strength between $15 \mathrm{MPa}$ and $170 \mathrm{MPa}$ and specimens with a diameter ranging from $51 \mathrm{~mm}$ to $406 \mathrm{~mm}$. Furthermore, this database includes specimens with a variety of FRP types: carbon FRP (CFRP), glass FRP (GFRP), high-modulus carbon FRP, aramid FRP (AFRP), CFRP tube, ultra-high-modulus CFRP tube, and AFRP tube. Finally, verifying the proposed model with the extensive database revealed that the proposed model has a very good level of prediction of the experimental results.
\end{abstract}

CE Database subject headings: Fiber reinforced polymer; Confinement; Concrete columns; Compressive strength; Strain; High-strength concrete.

\footnotetext{
${ }^{1}$ Ph.D. Candidate, School of Civil, Mining and Environmental Engineering, University of Wollongong, Wollongong, NSW 2522, Australia; Formerly, Lecturer, Faculty of Civil Engineering, HCMC University of Technology, Ho Chi Minh City 70000, Vietnam. Email: mtp027@uowmail.edu.au

${ }^{2}$ Associate Professor, School of Civil, Mining and Environmental Engineering, University of Wollongong, NSW 2522, Australia (corresponding author). Email: mhadi@uow.edu.au
} 


\section{Introduction}

Fiber-reinforced polymer (FRP) has been commonly used in practice as a confining material for concrete columns to enhance significantly their strength and ductility. The use of FRP has been applied to both normal strength concrete (NSC) and high strength concrete (HSC) under both concentric and eccentric loads (Mirmiran et al. 1998; Hadi and Li 2004; Hadi 2006; Hadi and Widiarsa 2012; Hadi et al. 2013; Pham et al. 2013). This use of FRP in industry has required design guidelines for these applications. Many confinement models for FRP confined concrete columns were therefore proposed to simulate the behavior of confined concrete columns (Karbhari and Gao 1997; Karabinis and Rousakis 2002; Lam and Teng 2003; Berthet et al. 2006; Matthys et al. 2006; Jiang and Teng 2007; Wu and Zhou 2010; Yazici and Hadi 2012). Most of the existing models are applicable for FRP confined NSC columns with exceptions of the models by Mandal et al. (2005), Cui and Sheikh (2010a), Berthet et al. (2006), and Xiao et al. (2010). It is noted that the model by Xiao et al. (2010) was developed for actively confined HSC. Therefore, it is necessary to develop a model to cover a wide range of unconfined concrete strength from NSC to HSC.

This study presents an overview of the existing models for FRP confined concrete circular sections. Column parameters affecting the ultimate condition of FRP confined concrete are discussed. In addition to the column parameters used in existing models, the proposed model for estimating the compressive strength of FRP confined concrete includes a new column parameter. The proposed strength model was established based on the principles of artificial neural networks (ANN) while the proposed strain model was developed using the energy approach. This study also collated an extensive database with varied FRP types to calibrate and verify the proposed model.

\section{Mechanism of confinement}


In this section, the key assumptions of existing strength models are studied and discussed. Most models for calculating the compressive strength of confined concrete have the following general form:

$$
\frac{f_{c c}^{\prime}}{f_{c o}^{\prime}}=1+k_{1} \frac{f_{l}}{f_{c o}^{\prime}}
$$

where $f_{c c}$ ' and $f_{c o}$ ' are the compressive strength of confined concrete and unconfined concrete, respectively, $f_{l}$ is the lateral confining pressure, and $k_{l}$ is the confinement effectiveness coefficient. The above form which was initially proposed by Richart et al. (1928) is based on tests of actively confined concrete with a value of 4.1 for $k_{l}$. The confining pressure could be calculated as follows:

$$
f_{l}=\frac{2 f_{f} t}{d}
$$

where $f_{f}$ is the tensile strength of FRP determined from flat coupon tests, $t$ is the thickness of FRP, and $d$ is the section diameter.

In addition, a few of the existing models had proposed a modified format of the above equation in the following form:

$$
\frac{f_{c c}^{\prime}}{f_{c o}^{\prime}}=1+k_{1}\left(\frac{f_{l}}{f_{c o}^{\prime}}\right)^{n}
$$

where $n$ is calibrated from a database.

In general, the value of $k_{l}$ could be a constant or a function of confinement ratio $\left(f_{l} / f_{c o}\right)$. This coefficient was attained by calibrating a database (Khalili and Fardis 1982; Karbhari and Gao 1997; Samaan et al. 1998; Toutanji 1999; Xiao and Wu 2000; Lam and Teng 2003; Bisby et al. 2005; Berthet et al. 2006; Matthys et al. 2006; Youssef et al. 2007). So, the accuracy of this coefficient depends on the size and reliability of the database used in their calibration. Ozbakkaloglu et al. (2013) have conducted an overview of 88 confinement models for FRP 
confined concrete in circular sections. From that study, it can be seen that the majority of equations for calculating the compressive strength of confined concrete are a function of the unconfined concrete strength $\left(f_{c o}{ }^{\prime}\right)$ and the confining pressure $\left(f_{l}\right)$.

A few other studies presented their models based on different forms or approaches. Mander et al. (1988) proposed a different form developed from a multiaxial failure surface for estimating the compressive strength of confined concrete as follows:

$$
f_{c c}^{\prime}=f_{c o}^{\prime}\left(-1.254+2.254 \sqrt{1+\frac{7.94 f_{l}}{f_{c o}^{\prime}}}-2 \frac{f_{l}}{f_{c o}^{\prime}}\right)
$$

The Mohr-Columb failure criterion was adopted by Shehata et al. (2002) and Li et al. (2003) to propose the following equation:

$$
f_{c c}^{\prime}=f_{c o}^{\prime}+f_{l} \tan ^{2}\left(45^{\circ}+\frac{\phi}{2}\right)
$$

where $\phi$ is the angle of internal friction of concrete.

Wu and Zhou (2010) adopted Hoek-Brown failure criterion (Hoek and Brown 1980) to propose the following equation for strength estimation:

$$
\frac{f_{c c}^{\prime}}{f_{c o}^{\prime}}=\frac{f_{l}}{f_{c o}^{\prime}}+\sqrt{\left(\frac{16.7}{\left(f_{c o}^{\prime}\right)^{0.42}}-\frac{\left(f_{c o}^{\prime}\right)^{0.42}}{16.7}\right) \frac{f_{l}}{f_{c o}^{\prime}}+1}
$$

As mentioned above, there are a few approaches to develop an equation for strength estimation of confined concrete. All of the above models assumed that the compressive strength of confined concrete is a function of the unconfined compressive strength of concrete and the confining pressure. In the following sections, this study will show some specimens which have been reported in the database and conducted by different researchers. They had 
very similar values of unconfined concrete strength and confining pressure but they had significant differences in the compressive strength of the confined concrete.

\section{Test database}

\section{General}

The test database used in this study contains experimental results of 574 FRP confined circular plain concrete columns. The test database was collated from several experimental tests being conducted over the past few decades (Ahmad et al. 1991; Nanni and Bradford 1995; Karbhari and Gao 1997; Mirmiran et al. 1998; Rochette and Labossière 2000; Xiao and Wu 2000; Zhang et al. 2000; Lin and Chen 2001; Karabinis and Rousakis 2002; Shehata et al. 2002; Li et al. 2003; Lam and Teng 2004; Lin and Liao 2004; Theriault et al. 2004; Au and Buyukozturk 2005; Berthet et al. 2005; Mandal et al. 2005; Matthys et al. 2005; Green et al. 2006; Lam et al. 2006; Saenz and Pantelides 2006; Shao et al. 2006; Silva and Rodrigues 2006; Wu et al. 2006; Yan et al. 2006; Almusallam 2007; Jiang and Teng 2007; Teng et al. 2007; Valdmanis et al. 2007; Youssef et al. 2007; Tamuzs et al. 2008; Wang and Wu 2008; Wong et al. 2008; Wu et al. 2008; Wu et al. 2009; Aire et al. 2010; Benzaid et al. 2010; Cui and Sheikh 2010b; Lee et al. 2010; Smith et al. 2010; Xiao et al. 2010). Other tests were conducted by Evans et al. (2008), Howie and Karbhari (1994), Ilki et al. (2002), Issa and Karam (2004), Miyauchi et al. (1999), Ongpeng (2006), Owen (1998), Rousakis et al. (2003), Suter and Pinzelli (2001), Comert et al. (2009), Micelli et al. (2001), Rousakis (2001), Chan et al. (2007), Kashyap (2007), and Wang (2008) as cited in Ozbakkaloglu and Lim (2013). The database contains a variety of FRP types: carbon FRP (CFRP, 317 specimens), glass FRP (GFRP, 119 specimens), high-modulus carbon FRP (HM CFRP, 45 specimens), aramid FRP (AFRP, 35 specimens), CFRP tube (28 specimens), ultra-high-modulus CFRP (UHM CFRP, 7 specimens) tube, and AFRP tube (23 specimens). The unconfined concrete strength in the 
database ranges between $15 \mathrm{MPa}$ and $170 \mathrm{MPa}$. The diameter of specimens varies between 51 $\mathrm{mm}$ and $406 \mathrm{~mm}$. The test database covers a wide range of FRP confinement levels $\left(f_{l} / f_{c o}{ }^{\prime}\right)$. The compressive strength of the most heavily confined specimen and the least lightly confined specimen increased by about $440 \%$ and $10 \%$, respectively. All specimens exhibiting a stress-strain curve with a descending branch, which is defined below, and specimens which showed a negligible strength increase were excluded from the database. Specimens damaged by premature rupture of FRP were also excluded from the database.

\section{Stress-strain curve}

The stress-strain relationship of FRP confined concrete is classified into two types: an ascending branch and a descending branch as shown in Fig. 1. This study only concerns the ascending branch type specimens. There are three key points of the stress-strain curve which are the ultimate strength of unconfined concrete, the transition point, and the ultimate strength of the confined concrete. The stress-strain relationship proposed by Lam and Teng (2003) is widely accepted and was adopted by ACI 440.2R (2008). This stress-strain relationship was adopted herein for FRP confined circular plain concrete specimens. It is also commonly accepted that the stress-strain relation is bi-linear. As such, once the ultimate stress/strain is precisely determined, the stress-strain curves should not be much different even though they could be calculated by different models. Therefore, determining the ultimate condition of FRP confined concrete plays an important role in a confinement model.

\section{Effect of confinement stiffness}

As mentioned above, many of the existing models have confirmed that only the unconfined concrete strength and the confining pressure affect significantly the compressive strength of FRP confined concrete. However, Teng et al. (2009) indicated that there were specimens with 
very similar unconfined concrete strength and confining pressure but they yielded different compressive strength of confined concrete. Teng et al. (2009) then introduced two new parameters that affect the compressive strength of confined concrete. The two new parameters are the confinement stiffness ratio $\left(\rho_{k}\right)$ and the strain ratio $\left(\rho_{\varepsilon}\right)$ :

$$
\begin{gathered}
\rho_{k}=\frac{2 E_{f} t}{\frac{f_{c o}^{\prime}}{\varepsilon_{c o}} d} \\
\rho_{\varepsilon}=\frac{\varepsilon_{f e}}{\varepsilon_{c o}}
\end{gathered}
$$

where $E_{f}$ is the plastic modulus of FRP, $\varepsilon_{c o}$ is the axial strain at peak stress of unconfined concrete, and $\varepsilon_{f e}$ is the actual rupture strain of FRP in the hoop direction. The compressive strength of confined concrete was calculated as:

$$
\frac{f_{c c}^{\prime}}{f_{c o}^{\prime}}=1+3.5\left(\rho_{k}-0.01\right) \rho_{\varepsilon}
$$

The equation above is used for specimens having $\rho_{k}$ greater than 0.01 . Table 1 was extracted from the full database to show that even though some specimens had very similar unconfined concrete strength and confining pressure, they had significant differences in the confined compressive strength. Due to space limitation, only six groups of typical test results are presented in Table 1. It is noted that the specimens in each group of Table 1 were conducted by different researchers and are named "pseudo-identical specimens". These specimens had different confinement stiffness ratio and strain ratio. As a result, their strengths were different as based on Teng et al.’s model (2009). 
Interestingly, Eq. 9 shows that the compressive strength of confined concrete must be in direct proportion to the value of $\left(\rho_{k}-0.01\right) \rho_{\varepsilon}$. It is found in Group 2 of Table 1 that the Columns $2 \mathrm{a}$ had the value of $\left(\rho_{k}-0.01\right) \rho_{\varepsilon}$ being greater than that of Columns $2 \mathrm{~b}$ but the value of $f_{c c}$ ' of Columns $2 \mathrm{a}$ is much smaller than that of Columns $2 \mathrm{~b}$. Similarly, the columns in Groups 3 and 6 also have the same indication. This observation may indicate that using the two new parameters do not well predict the compressive strength of confined concrete. In such cases, the FRP thickness ratio ( $t / d$ in Table 1$)$ can reflect the difference in these "pseudo-identical specimens" that have the same unconfined concrete strength and confining pressure but different confined compressive strength. The FRP thickness ratio is always in direct proportion to the compressive strength of confined concrete as confirmed by the database. Furthermore, Pham and Hadi (2014b) also took the FRP thickness ratio $(t / d)$ into account for calculating the compressive strength of FRP confined rectangular columns. Therefore, this study takes into account the unconfined concrete strength, the confining pressure and the FRP thickness ratio to calculate the compressive strength of confined concrete.

\section{Strength model for FRP confined circular concrete columns}

\section{The proposed strength model}

In order to calculate the compressive strength of FRP confined concrete columns, this study adopted a method proposed by Pham and Hadi (2014a) to generate a simple-form equation from a trained ANN. Pham and Hadi (2014a) concluded that the output could be calculated by multiplying the inputs by a proportional matrix if the proposed ANN is trained and yields good results. The inputs herein are column parameters of FRP confined concrete while the output is its confined compressive strength. It means that the compressive strength of confined concrete could be predicted by multiplying the column parameters by the proportional matrix. The proportional matrix is obtained by multiplying the input weight 
matrix by the layer weight matrix and normalizing the inputs and the outputs. Details of this method and definitions of some concepts could be found in the study by Pham and Hadi (2014a).

As mentioned above, the ratio between the FRP thickness and the section diameter affects the compressive strength of FRP confined concrete. Thus, three column parameters are considered in this model, which are the unconfined concrete strength $f_{c o}{ }^{\prime}(\mathrm{MPa})$, the confining pressure $f_{l}(\mathrm{MPa})$, and the ratio between the FRP thickness and the section diameter $t / d(\%)$. The compressive strength of FRP confined circular columns could be calculated as follows:

$$
f_{c c}^{\prime}=0.7 f_{c o}^{\prime}+1.8 f_{l}+5.7 \frac{t}{d}+13
$$

where the confining pressure $f_{l}$ is estimated from Eq. 2.

The proposed model could be used to estimate the compressive strength of confined concrete made of a variety of FRP types including CFRP, GFRP, AFRP, HM CFRP, UHM CFRP tube, CFRP tube, and AFRP tube. In addition, it is noted that Eq. 10 covers columns that have parameters in the ranges shown in Table 2.

\section{Verification of the strength model}

The proposed strength model was verified by the database including seven types of FRP and a wide range of compressive strength of unconfined concrete. Fig. 2 shows 574 data points of the predicted compressive strength of FRP confined concrete versus their experimental results. As shown in Fig. 2, the proposed strength model could predict the compressive strength of FRP-confined normal- and high-strength concrete circular columns. The compressive strength of unconfined concrete ranges between $15 \mathrm{MPa}$ and $170 \mathrm{MPa}$. In addition, the normalized predicted compressive strengths of confined columns versus their normalized experimental results are shown in Fig. 3. Five existing models were studied in this 
verification (Berthet et al. 2006; Matthys et al. 2006; Teng et al. 2009; Wu and Wang 2009; Yazici and Hadi 2012). The average absolute error (AAE), which is calculated using Eq. 11, of the above models ranges between $11.54 \%$ and $15.97 \%$. The proposed model shows the smallest value of AAE (9.88\%) among these models.

$$
A A E=\frac{\sum_{1}^{N}\left|\frac{\operatorname{pre}_{i}-\exp _{i}}{\exp _{i}}\right|}{N}
$$

where pre is the model predictions, exp is the experimental results, and $N$ is the total number of specimens. The mean square error (MSE) and the standard deviation (SD) are also calculated to assess the accuracy of the models:

$$
\begin{aligned}
& M S E=\frac{\sum_{1}^{N}\left(\frac{\text { pre }_{i}-\exp _{i}}{\exp _{i}}\right)^{2}}{N} \\
& S D=\sqrt{\frac{\sum_{1}^{N}\left(\frac{\operatorname{pre}_{i}}{\exp _{i}}-\frac{\operatorname{pre}_{\text {avg }}}{\exp _{\text {avg }}}\right)^{2}}{N-1}}
\end{aligned}
$$

Furthermore, the equation of the best-fit line (in the format $y=a x$ ) and the correlation factor $\left(R^{2}\right)$ in each model are reported. The five models above have a correlation factor ranging from 0.76 to 0.79 while that factor of the proposed models is 0.88 . The value of " $a$ " of the equation of the best-fit line could depict that the model is conservative $(a<1)$ or vice versa $(a>1)$. As can be easily seen in Fig. 3 that the models by Berthet et al. (2006), Teng et al. (2009), Wu and Wang (2009), and Yazici and Hadi (2012) are conservative while the model by Matthys et al. (2006) is less-conservative. Interestingly, the value of " $a$ " of the proposed strength model is equal to 1 . In addition, the error of the strength models was statistically verified and presented in Fig. 4. 


\section{Discussion of the proposed strength model}

Figs. 3-4 show that Eq. 10 compares well with the experimental data. However, the constant (value of 13) at the end of the equation may cause a considerable error in estimating the compressive strength of a specimen having low unconfined concrete strength and confining pressure. Consequently, the following equation is proposed as an approximation:

$$
f_{c c}^{\prime}=0.91 f_{c o}^{\prime}+1.88 f_{l}+7.6 \frac{t}{d}
$$

To verify the performance of Eq. 14, Fig. 5 shows the prediction results versus the experimental results. The error calculated from the prediction of Eq. 14 is slightly higher as compared to that of Eq. 10.

\section{Strain model for FRP confined circular concrete columns}

\section{Strain energy absorption}

The proposed strain model was developed based on the energy approach that was proposed by Pham and Hadi (2013). Pham and Hadi (2013) concluded that there is a linear relationship between the additional volumetric strain energy absorbed by a column core $\left(U_{c c}\right)$ and the volumetric strain energy absorbed by FRP $\left(U_{f}\right)$. When the strain of confined concrete is below the peak strain of the corresponding unconfined concrete, the effect of FRP is negligible. Thus, it is assumed that the additional energy in the column core equals the area under the experimental stress-strain curves starting from the value of unconfined concrete strain. The additional volumetric strain energy absorbed by a column core $\left(U_{c c}\right)$ is calculated as follows:

$$
U_{c c}=\int_{\varepsilon_{c o}}^{\varepsilon_{c c}} f_{c} d \varepsilon_{c}=\frac{\left(\varepsilon_{c c}-\varepsilon_{c o}\right)\left(f_{c o}^{\prime}+f_{c c}^{\prime}\right)}{2}
$$


where $f_{c}$ is the axial stress of the concrete, $d \varepsilon_{c}$ is an increment of the axial strain, $U_{c c}$ is the volumetric strain energy of confined concrete, $\varepsilon_{c c}$ is the ultimate strain of confined concrete. The volumetric strain energy absorbed by FRP $\left(U_{f}\right)$ could be determined as follows:

$$
U_{f}=\rho_{f}\left(\frac{1}{2} f_{f e} \varepsilon_{f e}\right)
$$

Where $\rho_{f}$ is the volumetric ratio of FRP and calculated as shown in Eq. 17, $U_{f}$ is the volumetric strain energy of FRP, and $f_{f e}$ and $\varepsilon_{f e}$ are the actual rupture strength and rupture strain of FRP on the columns, respectively.

$$
\rho_{f}=\frac{4 t}{d}
$$

\section{The proposed strain model}

The proposed strain model requires specimens including the actual rupture strain of FRP reported. Test results of specimens not reporting the actual rupture strain of FRP were excluded from the database. Thus, a new database (215 specimens) extracted from the full database was used to develop the proposed strain model. The new database covers unconfined concrete strength between $24 \mathrm{MPa}$ and $112 \mathrm{MPa}$, and a variety of FRP types including CFRP, GFRP, AFRP, HM CFRP, CFRP tube, and AFRP tube. The energy absorption of 215 specimens was determined using Eqs. 15 and 16, and the results are presented in Fig. 6. Next, a regression analysis was undertaken to attain the following equation:

$$
U_{c c}=6.62 U_{f}
$$

Substituting Eqs. 15 and 16 into Eq. 18, results in the following equation:

$$
\varepsilon_{c c}=\varepsilon_{c o}+\frac{4 k t f_{f e} \varepsilon_{f e}}{d\left(f_{c o}^{\prime}+f_{c c}^{\prime}\right)}
$$


where the proportion coefficient $k$ is equal to 6.62. This expression could be used to calculate the axial strain of CFRP confined concrete columns in circular sections. Using this calculated strain, any model could be utilized to calculate the confined concrete strength. Lam and Teng model (2003) was adopted to express another form of Eq. 19 as follows:

$$
\varepsilon_{c c}=\varepsilon_{c o}+\frac{2 k t f_{f e} \varepsilon_{f e}}{d f_{c o}^{\prime}+3.3 f_{f e} t}
$$

\section{Verification of the strain model}

Fig. 7 shows theoretical strain versus experimental strain of FRP confined circular columns. This figure depicts that the proposed strain model predicts both the 132 NSC columns and the 83 HSC columns. This figure also shows that the proposed model's prediction of columns with low compressive strain is closer to experimental results than the others. The errors of the model's prediction in a range of high strain could be explained through Fig. 6, which describes that the relationship between the two energies of columns having low energy absorption is more correlative than the columns that have high energy absorbed.

In addition, a total of 215 data points are plotted in Fig. 8 to assess the performance of existing models and the proposed model. Five strain models were considered in this verification (De Lorenzis and Tepfers 2003; Lam and Teng 2003; Teng et al. 2009; Rousakis et al. 2012; Yazici and Hadi 2012). The performance and accuracy of all six models are comparable with the value of AAE ranging from $19 \%$ to $36 \%$. Among the above models, the proposed strain model shows the best performance with the AAE of 19\%. In general trend, the model by Teng et al. (2009) and the proposed model depict good prediction for all ranges of columns' strain. The model by De Lorenzis and Tepfers (2003) also shows very good agreement between the predicted and the experimental results. However, this model is very 
conservative in a range of columns having high compressive axial strain. In addition, the error of the strain models was statistically verified and presented in Fig. 9.

\section{Conclusions}

A confinement model was developed for FRP confined normal- and high-strength concrete columns. The predictions of the proposed model fit the experimental results from the extensive database very well. The findings presented in this paper are summarized as follows:

1. In order to calculate the compressive strength of FRP confined circular columns, the ratio between the thickness of FRP and the column diameter should be taken into account. When this parameter is considered, only a unified equation is used to calculate the compressive strength of confined concrete with different FRP types, which have significant difference in the jacket stiffness.

2. The proposed model could estimate the compressive strength of confined concrete with unconfined concrete strength ranging between $15 \mathrm{MPa}$ and $170 \mathrm{MPa}$.

3. This study confirms that using the energy method could estimate well the compressive strain of FRP confined concrete as compared to experimental results. This study refines the applicability of the energy-based strain model proposed by Pham and Hadi (2013) from only CFRP to seven types of FRP.

Finally, this study takes the FRP thickness ratio into account to predict the compressive strength of FRP confined circular concrete columns. This consideration provides a unified equation covering all types of FRP and diminishes the disadvantage of most of the existing models that propose a different experimental factor for each FRP type.

\section{Acknowledgement}


The first author would like to acknowledge the Vietnamese Government and the University of Wollongong for the support of his full PhD scholarship. 


\section{References}

ACI 440.2R-08. (2008). "Guide for the Design and Construction of Externally Bonded FRP Systems for Strengthening Concrete Structures." 440.2R-08, Farmington Hills, MI.

Ahmad, S.H., Khaloo, A.R., and Irshaid, A. (1991). "Behavior of Concrete Spirally Condined by Fiberglass Filaments." Magazine of Concrete Research, 43(156), 143-148.

Aire, C., Gettu, R., Casas, J.R., Marques, S., and Marques, D. (2010). "Concrete laterally confined with fibre-reinforced polymers (FRP): experimental study and theoretical model." Materiales de Construccion, 60(297), 19-31.

Almusallam, T.H. (2007). "Behavior of normal and high-strength concrete cylinders confined with E-glass/epoxy composite laminates." Composites Part B: Engineering, 38(5), 629-639.

$\mathrm{Au}, \mathrm{C}$., and Buyukozturk, O. (2005). "Effect of fiber orientation and ply mix on fiber reinforced polymer-confined concrete." Journal of Composites for Construction, 9(5), 397407.

Benzaid, R., Mesbah, H., and Chikh, N.E. (2010). "FRP-confined Concrete Cylinders: Axial Compression Experiments and Strength Model." Journal of Reinforced Plastics and Composites, 29(16), 2469-2488.

Berthet, J.F., Ferrier, E., and Hamelin, P. (2005). "Compressive behavior of concrete externally confined by composite jackets. Part A: experimental study." Construction and Building Materials, 19(3), 223-232.

Berthet, J.F., Ferrier, E., and Hamelin, P. (2006). "Compressive behavior of concrete externally confined by composite jackets: Part B: modeling." Construction and Building Materials, 20(5), 338-347.

Bisby, L.A., Dent, A.J.S., and Green, M.F. (2005). "Comparison of confinement models for fiber-reinforced polymer-wrapped concrete." ACI Structural Journal, 102(1), 62-72.

Cui, C., and Sheikh, S.A. (2010a). "Analytical Model for Circular Normal- and High-Strength Concrete Columns Confined with FRP." Journal of Composites for Construction, 14(5), 562572 .

Cui, C., and Sheikh, S.A. (2010b). "Experimental Study of Normal- and High-Strength Concrete Confined with Fiber-Reinforced Polymers." Journal of Composites for Construction, 14(5), 553-561.

De Lorenzis, L., and Tepfers, R. (2003). "Comparative Study of Models on Confinement of Concrete Cylinders with Fiber-Reinforced Polymer Composites." Journal of Composites for Construction, 7(3), 219-237.

Green, M.F., Bisby, L.A., Fam, A.Z., and Kodur, V.K.R. (2006). "FRP confined concrete columns: Behaviour under extreme conditions." Cement and Concrete Composites, 28(10), 928-937.

Hadi, M.N.S. (2006). "Behaviour of FRP wrapped normal strength concrete columns under eccentric loading." Composite Structures, 72(4), 503-511.

Hadi, M.N.S., and Li, J. (2004). "External reinforcement of high strength concrete columns." Composite Structures, 65(3-4), 279-287. 
Hadi, M.N.S., Pham, T.M., and Lei, X. (2013). "New Method of Strengthening Reinforced Concrete Square Columns by Circularizing and Wrapping with Fiber-Reinforced Polymer or Steel Straps." Journal of Composites for Construction, 17(2), 229-238.

Hadi, M.N.S., and Widiarsa, I.B.R. (2012). "Axial and Flexural Performance of Square RC Columns Wrapped with CFRP under Eccentric Loading." Journal of Composites for Construction, 16(6), 640-649.

Hoek, E., and Brown, E.T. (1980). "Empirical Strength Criterion for Rock Masses." Journal of the Geotechnical Engineering Division, 106(Compendex), 1013-1035.

Jiang, T., and Teng, J.G. (2007). "Analysis-oriented stress-strain models for FRP-confined concrete." Engineering Structures, 29(11), 2968-2986.

Karabinis, A.I., and Rousakis, T.C. (2002). "Concrete confined by FRP material: a plasticity approach." Engineering Structures, 24(7), 923-932.

Karbhari, V.M., and Gao, Y. (1997). "Composite Jacketed Concrete under Uniaxial Compression Verification of Simple Design Equations." Journal of Materials in Civil Engineering, 9(4), 185-193.

Khalili, H.H., and Fardis, M.N. (1982). "FRP-encased concrete as a structural material." Magazine of Concrete Research, 34(121), 191-202.

Lam, L., and Teng, J.G. (2003). "Design-oriented stress-strain model for FRP-confined concrete." Construction and Building Materials, 17(6-7), 471-489.

Lam, L., and Teng, J.G. (2004). "Ultimate condition of fiber reinforced polymer-confined concrete." Journal of Composites for Construction, 8(6), 539-548.

Lam, L., Teng, J.G., Cheung, C.H., and Xiao, Y. (2006). "FRP-confined concrete under axial cyclic compression." Cement and Concrete Composites, 28(10), 949-958.

Lee, J., Y., Yi, C., K., Jeong, H., S., Kim, S., W., and Kim, J., K. (2010). "Compressive Response of Concrete Confined with Steel Spirals and FRP Composites." Journal of Composite Materials, 44(4), 481-504.

Li, Y.-F., Lin, C.-T., and Sung, Y.-Y. (2003). "A constitutive model for concrete confined with carbon fiber reinforced plastics." Mechanics of Materials, 35(3), 603-619.

Lin, H.-J., and Liao, C.-I. (2004). "Compressive strength of reinforced concrete column confined by composite material." Composite Structures, 65(2), 239-250.

Lin, H., J., and Chen, C., T. (2001). "Strength of Concrete Cylinder Confined by Composite Materials." Journal of Reinforced Plastics and Composites, 20(18), 1577-1600.

Mandal, S., Hoskin, A., and Fam, A. (2005). "Influence of concrete strength on confinement effectiveness of fiber-reinforced polymer circular jackets." ACI Structural Journal, 102(3), 383-392.

Mander, J.B., Park, R., and Priestley, M.J.N. (1988). "Theoretical Stress-Strain Model for Confined Concrete." Journal of Structural Engineering, 114(8), 1804-1826.

Matthys, S., Toutanji, H., Audenaert, K., and Taerwe, L. (2005). "Axial load behavior of large-scale columns confined with fiber-reinforced polymer composites." ACI Structural Journal, 102(2), 258-267. 
Matthys, S., Toutanji, H., and Taerwe, L. (2006). "Stress-strain behavior of large-scale circular columns confined with FRP composites." Journal of Structural Engineering, 132(1), 123-133.

Mirmiran, A., Shahawy, M., Samaan, M., Echary, H.E., Mastrapa, J.C., and Pico, O. (1998). "Effect of Column Parameters on FRP-Confined Concrete." Journal of Composites for Construction, 2(4), 175-185.

Nanni, A., and Bradford, N.M. (1995). "FRP jacketed concrete under uniaxial compression." Construction and Building Materials, 9(2), 115-124.

Ozbakkaloglu, T., and Lim, J.C. (2013). "Axial compressive behavior of FRP-confined concrete: Experimental test database and a new design-oriented model." Composites Part B: Engineering, 55(0), 607-634.

Ozbakkaloglu, T., Lim, J.C., and Vincent, T. (2013). "FRP-confined concrete in circular sections: Review and assessment of stress-strain models." Engineering Structures, 49(0), 1068-1088.

Pham, T.M., Doan, L.V., and Hadi, M.N.S. (2013). "Strengthening square reinforced concrete columns by circularisation and FRP confinement." Construction and Building Materials, 49(0), 490-499.

Pham, T.M., and Hadi, M.N.S. (2013). "Strain Estimation of CFRP Confined Concrete Columns Using Energy Approach." Journal of Composites for Construction, 17(6), 04013001.

Pham, T.M., and Hadi, M.N.S. (2014a). "Predicting Stress and Strain of FRP Confined Rectangular/Square Columns Using Artificial Neural Networks." Journal of Composites for Construction, (Revision submitted).

Pham, T.M., and Hadi, M.N.S. (2014b). "Stress Prediction Model for FRP Confined Rectangular Concrete Columns with Rounded Corners." Journal of Composites for Construction, 18(1), 04013019.

Richart, F.E., Brandtzaeg, A., and Brown, R.L. (1928). "A study of the failure of concrete under combined compressive stress." Bulletin 1985, Univ. of Illinois Engineering Experimental Station, Champaign, III.

Rochette, P., and Labossière, P. (2000). "Axial Testing of Rectangular Column Models Confined with Composites." Journal of Composites for Construction, 4(3), 129-136.

Rousakis, T., Rakitzis, T., and Karabinis, A. (2012). Empirical Modelling of Failure Strains of Uniformly FRP Confined Concrete Columns. The 6th International Conference on FRP Composites in Civil Engineering - CICE 2012, Rome.

Saenz, N., and Pantelides, C. (2006). "Short and Medium Term Durability Evaluation of FRPConfined Circular Concrete." Journal of Composites for Construction, 10(3), 244-253.

Samaan, M., Mirmiran, A., and Shahawy, M. (1998). "Model of concrete confined by fiber composites." Journal of Structural Engineering, 124(9), 1025-1031.

Shao, Y., Zhu, Z., and Mirmiran, A. (2006). "Cyclic modeling of FRP-confined concrete with improved ductility." Cement and Concrete Composites, 28(10), 959-968.

Shehata, I.A.E.M., Carneiro, L.A.V., and Shehata, L.C.D. (2002). "Strength of short concrete columns confined with CFRP sheets." Materials and Structures, 35(1), 50-58. 
Silva, M.A.G., and Rodrigues, C.C. (2006). "Size and Relative Stiffness Effects on Compressive Failure of Concrete Columns Wrapped with Glass FRP." Journal of Materials in Civil Engineering, 18(3), 334-342.

Smith, S.T., Kim, S.J., and Zhang, H.W. (2010). "Behavior and Effectiveness of FRP Wrap in the Confinement of Large Concrete Cylinders." Journal of Composites for Construction, 14(5), 573-582.

Tamuzs, V., Valdmanis, V., Tepfers, R., and Gylltoft, K. (2008). "Stability analysis of CFRPwrapped concrete columns strengthened with external longitudinal CFRP sheets." Mechanics of Composite Materials, 44(3), 199-208.

Teng, J.G., Huang, Y.L., Lam, L., and Ye, L.P. (2007). "Theoretical model for fiberreinforced polymer-confined concrete." Journal of Composites for Construction, 11(2), 201210.

Teng, J.G., Jiang, T., Lam, L., and Luo, Y.Z. (2009). "Refinement of a Design-Oriented Stress-Strain Model for FRP-Confined Concrete." Journal of Composites for Construction, 13(4), 269-278.

Theriault, M., Neale, K.W., and Claude, S. (2004). "Fiber-Reinforced Polymer-Confined Circular Concrete Columns: Investigation of Size and Slenderness Effects." Journal of Composites for Construction, 8(4), 323-331.

Toutanji, H.A. (1999). "Stress-strain characteristics of concrete columns externally confined with advanced fiber composite sheets." ACI Materials Journal, 96(3), 397-404.

Valdmanis, V., De Lorenzis, L., Rousakis, T., and Tepfers, R. (2007). "Behaviour and capacity of CFRP-confined concrete cyliners subjected to monotonic and cyclic axial compressive load." Structural Concrete, 8(4), 187-190.

Wang, L.M., and Wu, Y.F. (2008). "Effect of corner radius on the performance of CFRPconfined square concrete columns: Test." Engineering Structures, 30(2), 493-505.

Wong, Y.L., Yu, T., Teng, J.G., and Dong, S.L. (2008). "Behavior of FRP-confined concrete in annular section columns." Composites Part B: Engineering, 39(3), 451-466.

Wu, G., Wu, Z.S., Lu, Z.T., and Ando, Y.B. (2008). "Structural Performance of Concrete Confined with Hybrid FRP Composites." Journal of Reinforced Plastics and Composites, 27(12), 1323-1348.

Wu, H.L., Wang, Y.F., Yu, L., and Li, X.R. (2009). "Experimental and Computational Studies on High-Strength Concrete Circular Columns Confined by Aramid Fiber-Reinforced Polymer Sheets." Journal of Composites for Construction, 13(2), 125-134.

Wu, Y.F., Liu, T., and Oehlers, D.J. (2006). "Fundamental principles that govern retrofitting of reinforced concrete columns by steel and FRP jacketing." Advances in Structural Engineering, 9(4), 507-533.

Wu, Y.F., and Wang, L.M. (2009). "Unified Strength Model for Square and Circular Concrete Columns Confined by External Jacket." Journal of Structural Engineering, 135(3), 253-261.

Wu, Y.F., and Zhou, Y.W. (2010). "Unified Strength Model Based on Hoek-Brown Failure Criterion for Circular and Square Concrete Columns Confined by FRP." Journal of Composites for Construction, 14(2), 175-184.

Xiao, Q.G., Teng, J.G., and Yu, T. (2010). "Behavior and Modeling of Confined HighStrength Concrete." Journal of Composites for Construction, 14(3), 249-259. 
Xiao, Y., and Wu, H. (2000). "Compressive behavior of concrete confined by carbon fiber composite jackets." Journal of Materials in Civil Engineering, 12(2), 139-146.

Yan, Z.H., Pantelides, C.P., and Reaveley, L.D. (2006). "Fiber-reinforced polymer jacketed and shape-modified compression members: I - Experimental behavior." ACI Structural Journal, 103(6), 885-893.

Yazici, V., and Hadi, M.N.S. (2012). "Normalized Confinement Stiffness Approach for Modeling FRP-Confined Concrete." Journal of Composites for Construction, 16(5), 520-528.

Youssef, M.N., Feng, M.Q., and Mosallam, A.S. (2007). "Stress-strain model for concrete confined by FRP composites." Composites Part B: Engineering, 38(5), 614-628.

Zhang, S., Ye, L., and Mai, Y.W. (2000). "A study on polymer composite strengthening systems for concrete columns." Applied Composite Materials, 7(2-3), 125-138. 


\section{List of Figures}

Figure 1. Stress-strain relationship of FRP confined concrete

Figure 2. Performance of the proposed model for both NSC and HSC specimens

Figure 3. Comparison of the selected strength models

Figure 4. Accuracy of the selected strength models

Figure 5. Performance of the modified proposed model

Figure 6. Energy relationship of FRP confined circular columns

Figure 7. Performance of the proposed strain model

Figure 8. Comparison of the selected strain models

Figure 9. Accuracy of the selected strain models 


\section{List of Tables}

Table 1. Pseudo-identical specimens in the database

Table 2. Range of the column parameters for the proposed strength model 
Table 1. Pseudo-identical specimens in the database

\begin{tabular}{|c|c|c|c|c|c|c|c|c|c|}
\hline $\begin{array}{c}\text { Group } \\
\text { No. }\end{array}$ & Sources & $\underset{(\mathrm{mm})}{d}$ & $\begin{array}{c}\dot{f}_{c o}^{\prime} \\
(\mathrm{MPa})\end{array}$ & $\begin{array}{c}f_{l} \\
(\mathrm{MPa})\end{array}$ & $\begin{array}{l}t / d \\
(\%)\end{array}$ & $\begin{array}{c}\dot{f}_{c c}^{\prime} \\
(\mathrm{MPa})\end{array}$ & $\rho_{k}$ & $\rho_{\varepsilon}$ & $\left(\rho_{k}-0.01\right) \rho_{\varepsilon}$ \\
\hline \multirow{4}{*}{$1 \mathrm{a}$} & Mirmiran et al. (1998) & 152 & 29.8 & 19.5 & 0.5 & 63.0 & 0.04 & 9.4 & 0.27 \\
\hline & Mirmiran et al. (1998) & 152 & 29.8 & 19.5 & 0.5 & 58.7 & 0.04 & 9.4 & 0.27 \\
\hline & Mirmiran et al. (1998) & 152 & 31.2 & 19.5 & 0.5 & 63.1 & 0.04 & 9.2 & 0.25 \\
\hline & Mirmiran et al. (1998) & 152 & 31.2 & 19.5 & 0.5 & 65.4 & 0.04 & 9.2 & 0.25 \\
\hline \multirow{6}{*}{$1 \mathrm{~b}$} & Silva and Rodrigues (2006) & 150 & 31.1 & 19.9 & 1.7 & 91.6 & 0.07 & 8.3 & 0.49 \\
\hline & Silva and Rodrigues (2006) & 150 & 29.6 & 19.9 & 1.7 & 89.4 & 0.07 & 5.0 & 0.32 \\
\hline & Silva and Rodrigues (2006) & 150 & 31.1 & 19.9 & 1.7 & 87.5 & 0.07 & 7.9 & 0.47 \\
\hline & Silva and Rodrigues (2006) & 150 & 31.1 & 19.9 & 1.7 & 91.9 & 0.07 & 7.8 & 0.46 \\
\hline & Silva and Rodrigues (2006) & 150 & 29.6 & 19.9 & 1.7 & 89.8 & 0.07 & 5.0 & 0.32 \\
\hline & Silva and Rodrigues (2006) & 150 & 31.2 & 19.9 & 1.7 & 91.9 & 0.07 & 8.0 & 0.48 \\
\hline \multirow{2}{*}{$2 \mathrm{a}$} & Xiao and $\mathrm{Wu}(2000)$ & 152 & 33.7 & 23.7 & 0.8 & 82.9 & 0.09 & 4.1 & 0.34 \\
\hline & Xiao and Wu (2000) & 152 & 33.7 & 23.7 & 0.8 & 86.2 & 0.09 & 4.5 & 0.38 \\
\hline \multirow{2}{*}{$2 b$} & Lin and Chen (2001) & 120 & 32.7 & 22.3 & 1.5 & 101.3 & 0.06 & 6.3 & 0.31 \\
\hline & Lin and Chen (2001) & 120 & 32.7 & 22.3 & 1.5 & 104.5 & 0.06 & 6.3 & 0.31 \\
\hline \multirow{2}{*}{$3 a$} & Jiang and Teng (2007) & 152 & 45.9 & 12.3 & 0.3 & 64.6 & 0.03 & 6.6 & 0.12 \\
\hline & Jiang and Teng (2007) & 152 & 45.9 & 12.3 & 0.3 & 65.9 & 0.03 & 8.0 & 0.15 \\
\hline \multirow{3}{*}{$3 b$} & Youssef et al. (2007) & 152 & 44.1 & 12.5 & 1.5 & 80.4 & 0.03 & 5.3 & 0.10 \\
\hline & Youssef et al. (2007) & 152 & 44.1 & 12.5 & 1.5 & 80.0 & 0.03 & 5.3 & 0.10 \\
\hline & Youssef et al. (2007) & 152 & 44.1 & 12.5 & 1.5 & 81.1 & 0.03 & 5.3 & 0.10 \\
\hline \multirow{2}{*}{$4 \mathrm{a}$} & Cui and Sheikh (2010) & 152 & 48.1 & 21.5 & 1.3 & 109.4 & 0.10 & 4.4 & 0.41 \\
\hline & Cui and Sheikh (2010) & 152 & 48.1 & 21.5 & 1.3 & 126.7 & 0.10 & 5.5 & 0.51 \\
\hline \multirow{2}{*}{$4 \mathrm{~b}$} & Tamuzs et al. (2008) & 150 & 48.8 & 20.4 & 0.2 & 72.1 & 0.05 & 1.8 & 0.08 \\
\hline & Tamuzs et al. (2008) & 150 & 48.8 & 20.4 & 0.2 & 72.6 & 0.05 & 1.5 & 0.07 \\
\hline \multirow{2}{*}{$5 \mathrm{a}$} & Cui and Sheikh (2010) & 152 & 48.1 & 32.2 & 2.0 & 162.7 & 0.15 & 5.2 & 0.76 \\
\hline & Cui and Sheikh (2010) & 152 & 48.1 & 32.2 & 2.0 & 153.6 & 0.15 & 4.7 & 0.68 \\
\hline $5 b$ & Rousakis et al. (2003) & 150 & 49.2 & 30.6 & 0.3 & 100.6 & 0.05 & 6.2 & 0.28 \\
\hline $6 a$ & Aire et al. (2010) & 150 & 69 & 36.5 & 0.5 & 156.0 & 0.08 & 4.3 & 0.29 \\
\hline $6 \mathrm{~b}$ & Xiao et al. (2010) & 152 & 70.8 & 36.7 & 0.7 & 180.5 & 0.14 & 2.0 & 0.27 \\
\hline
\end{tabular}


Table 2. Range of the column parameters for the proposed strength model

\begin{tabular}{lcc}
\hline & Max & Min \\
\hline$f_{c o}{ }^{\prime}(\mathrm{MPa})$ & 170 & 15 \\
$f_{l}(\mathrm{MPa})$ & 109 & 3 \\
$t / d(\%)$ & 3.9 & 0.06 \\
$f_{c c}{ }^{\prime}(\mathrm{MPa})$ & 296 & 37 \\
\hline
\end{tabular}




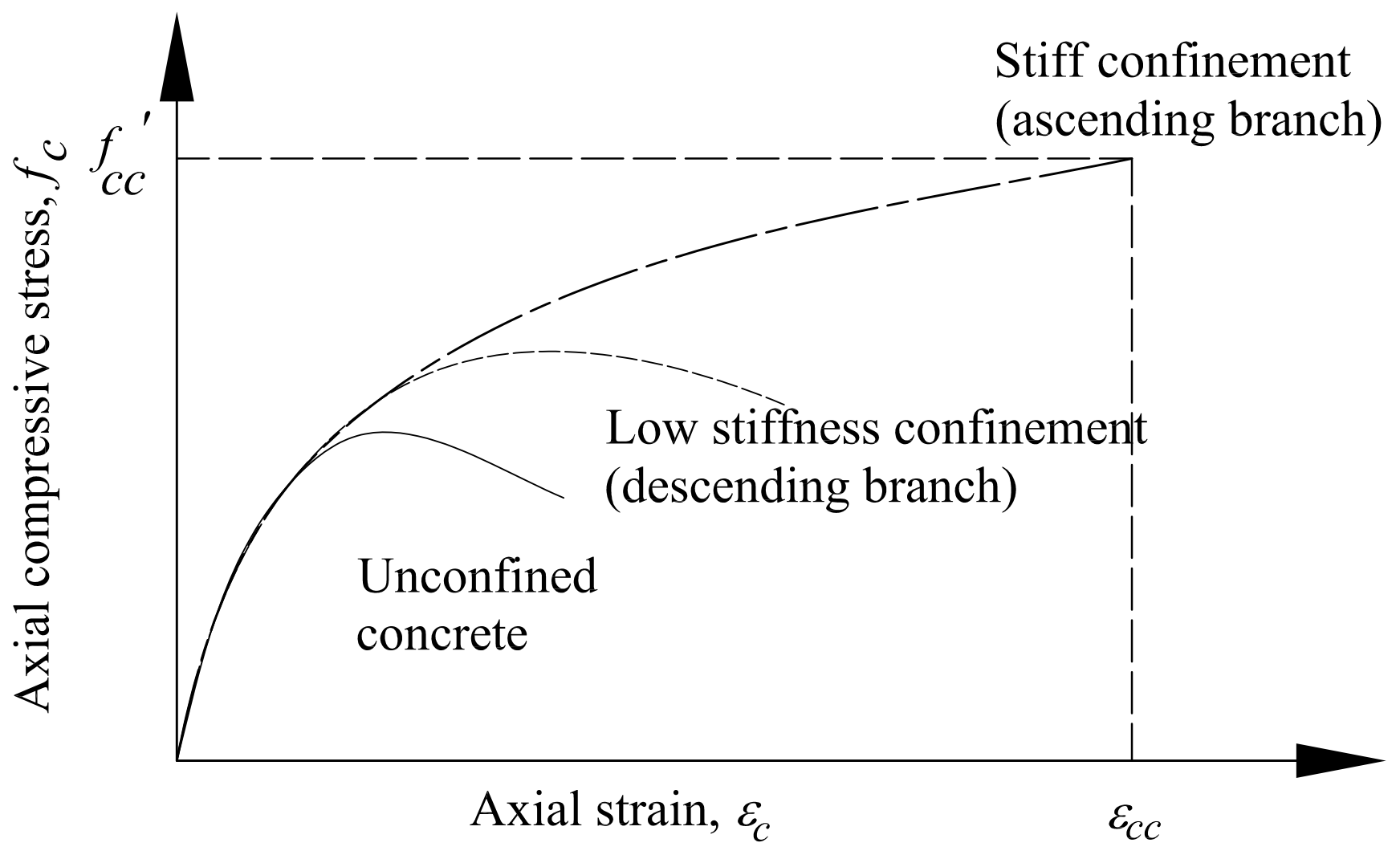




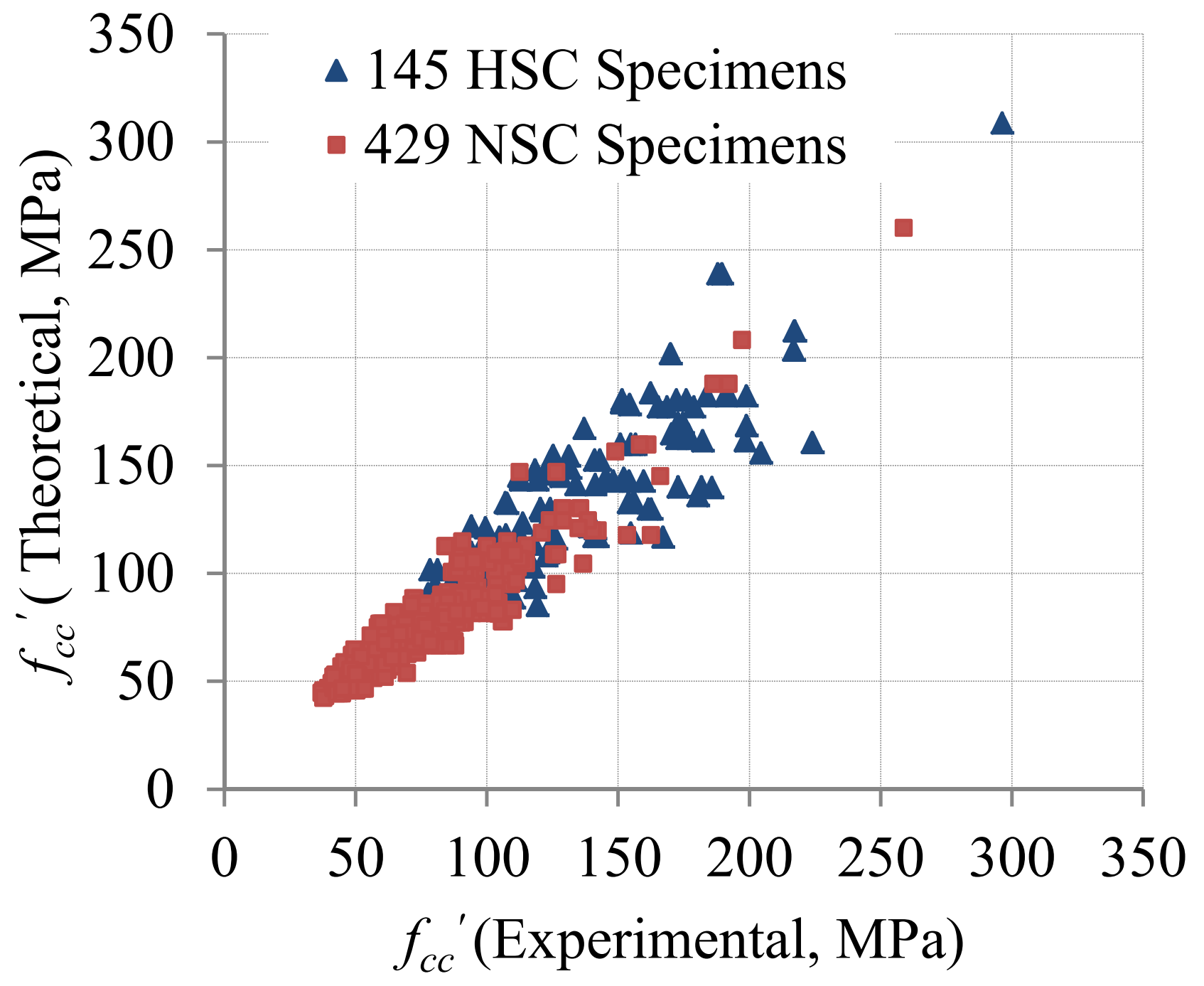



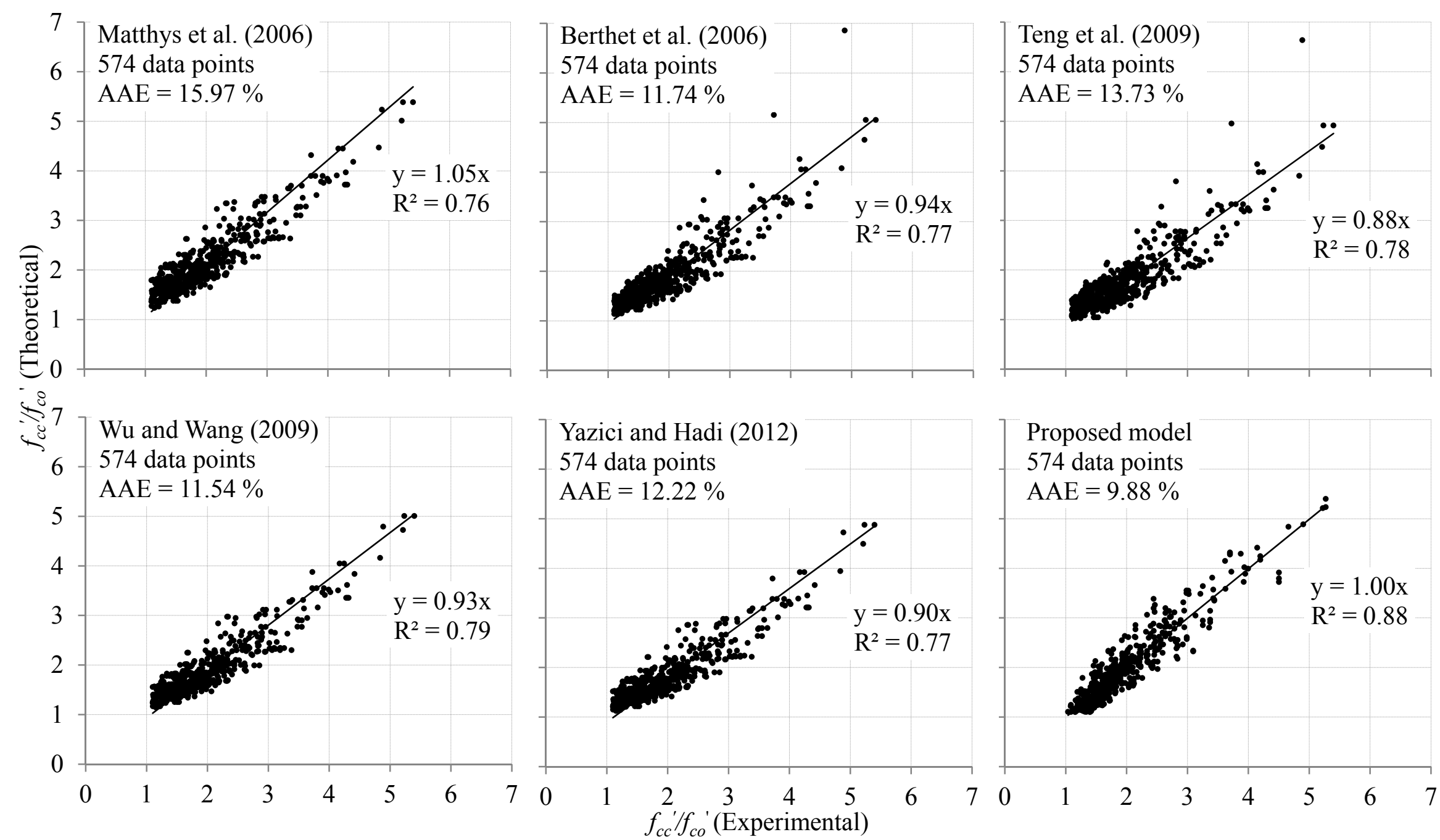


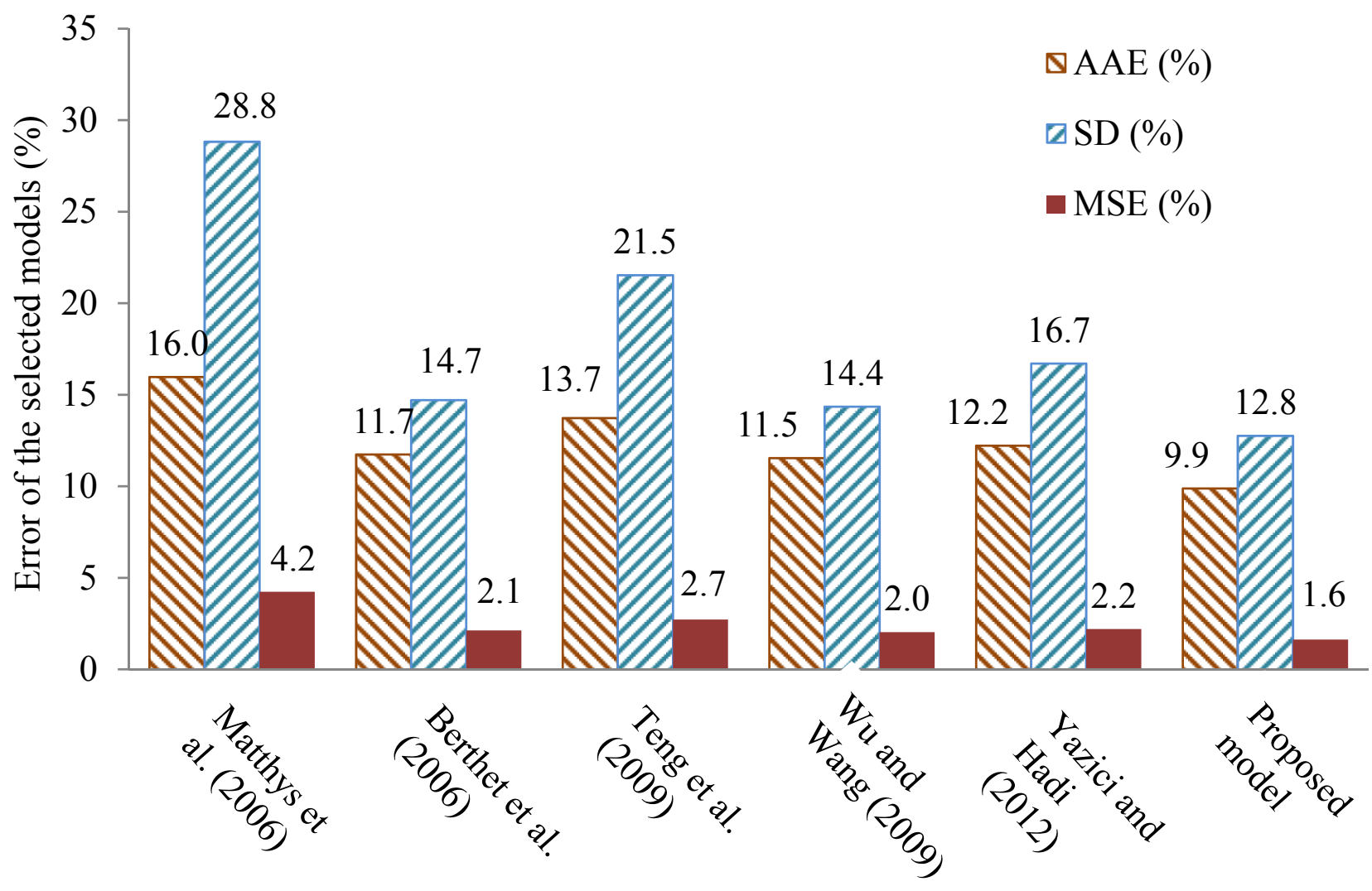




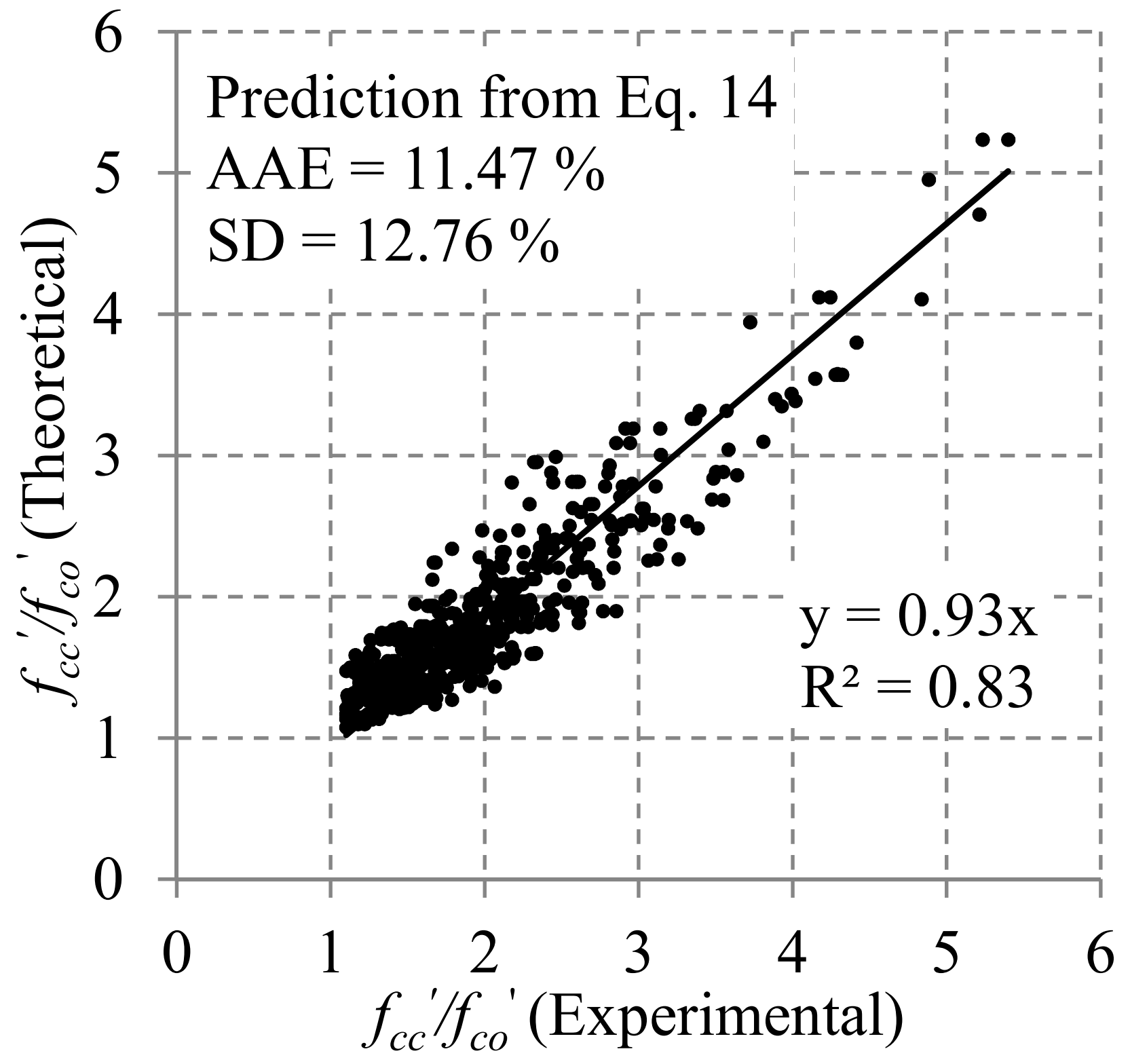




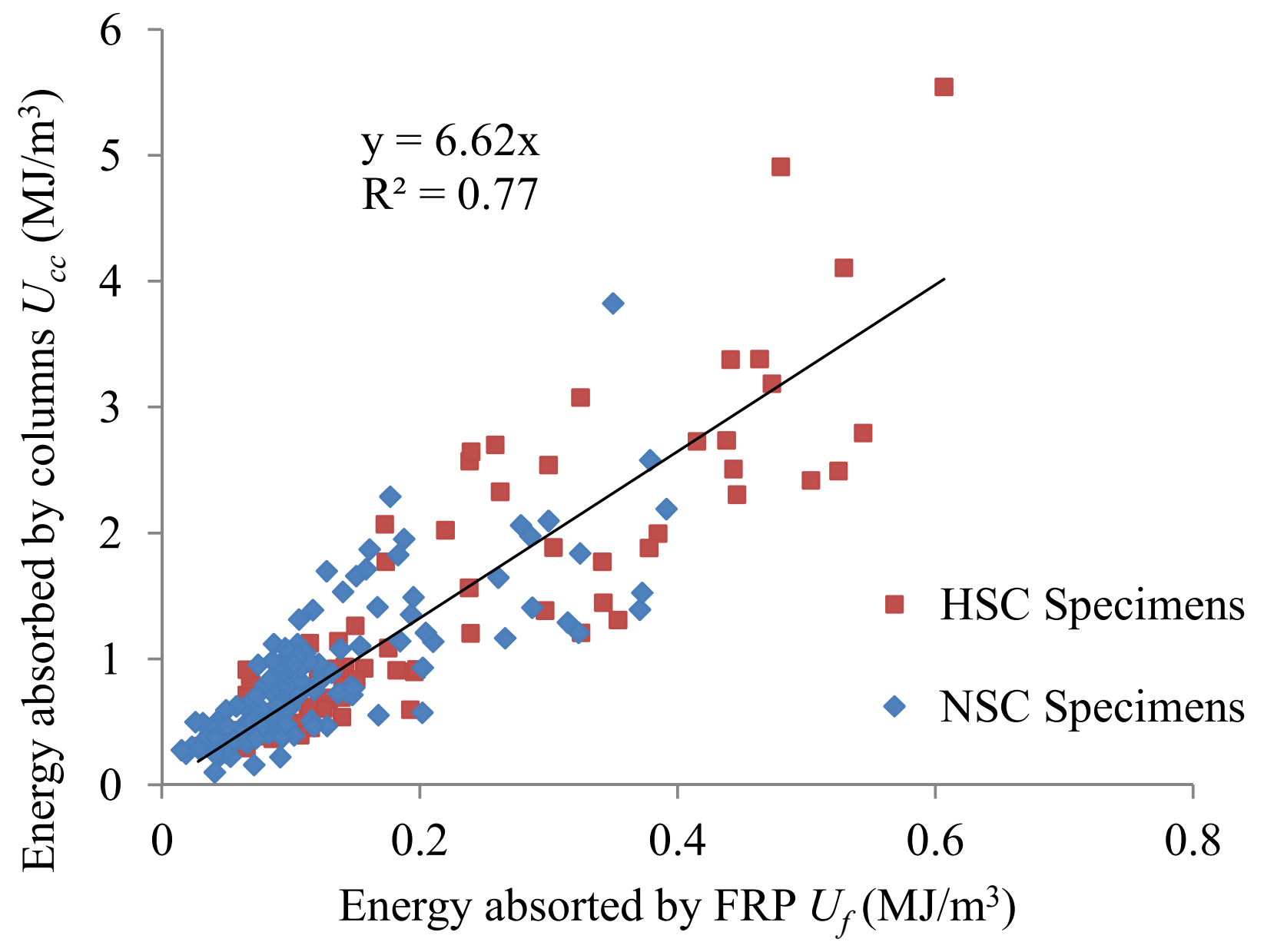




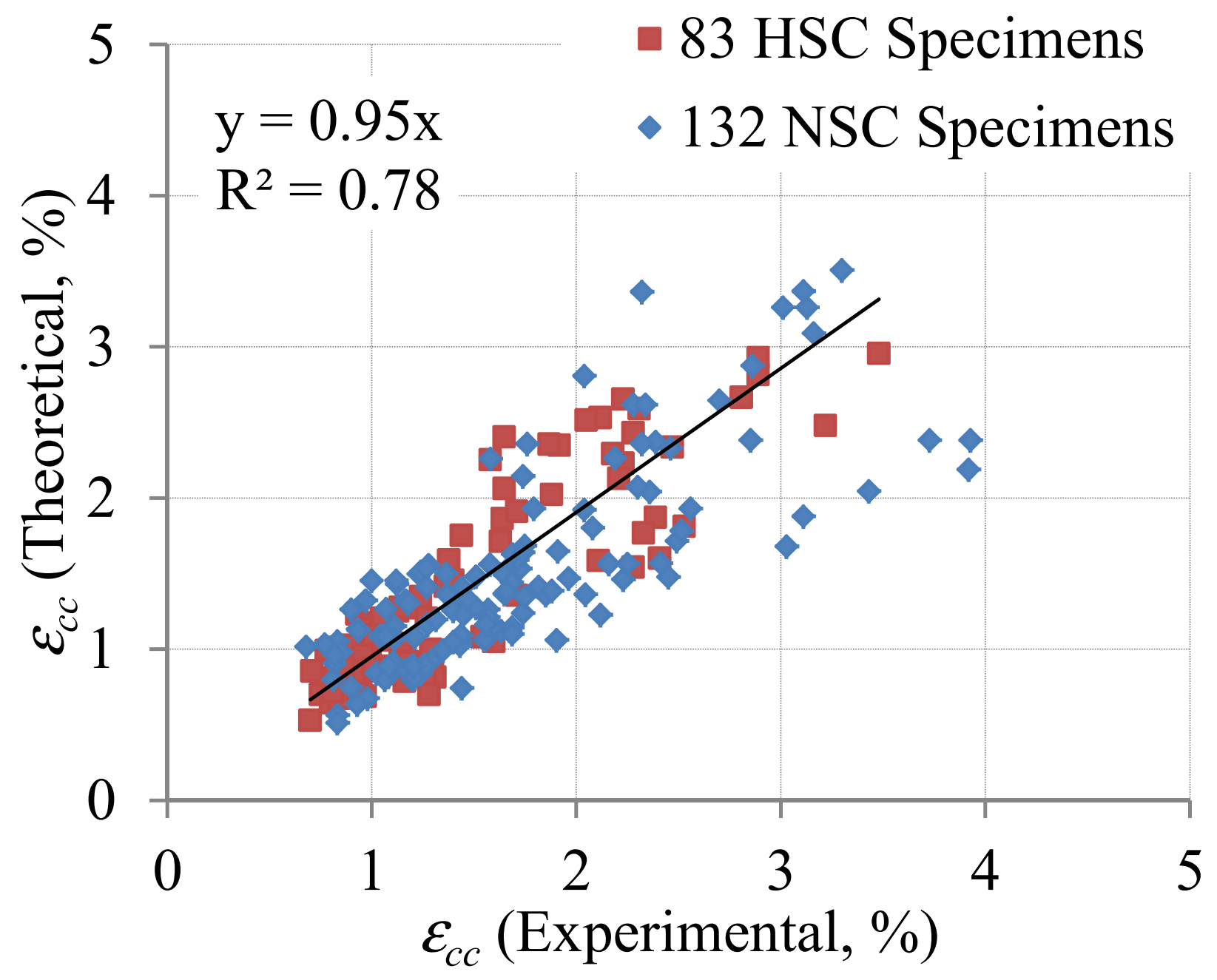



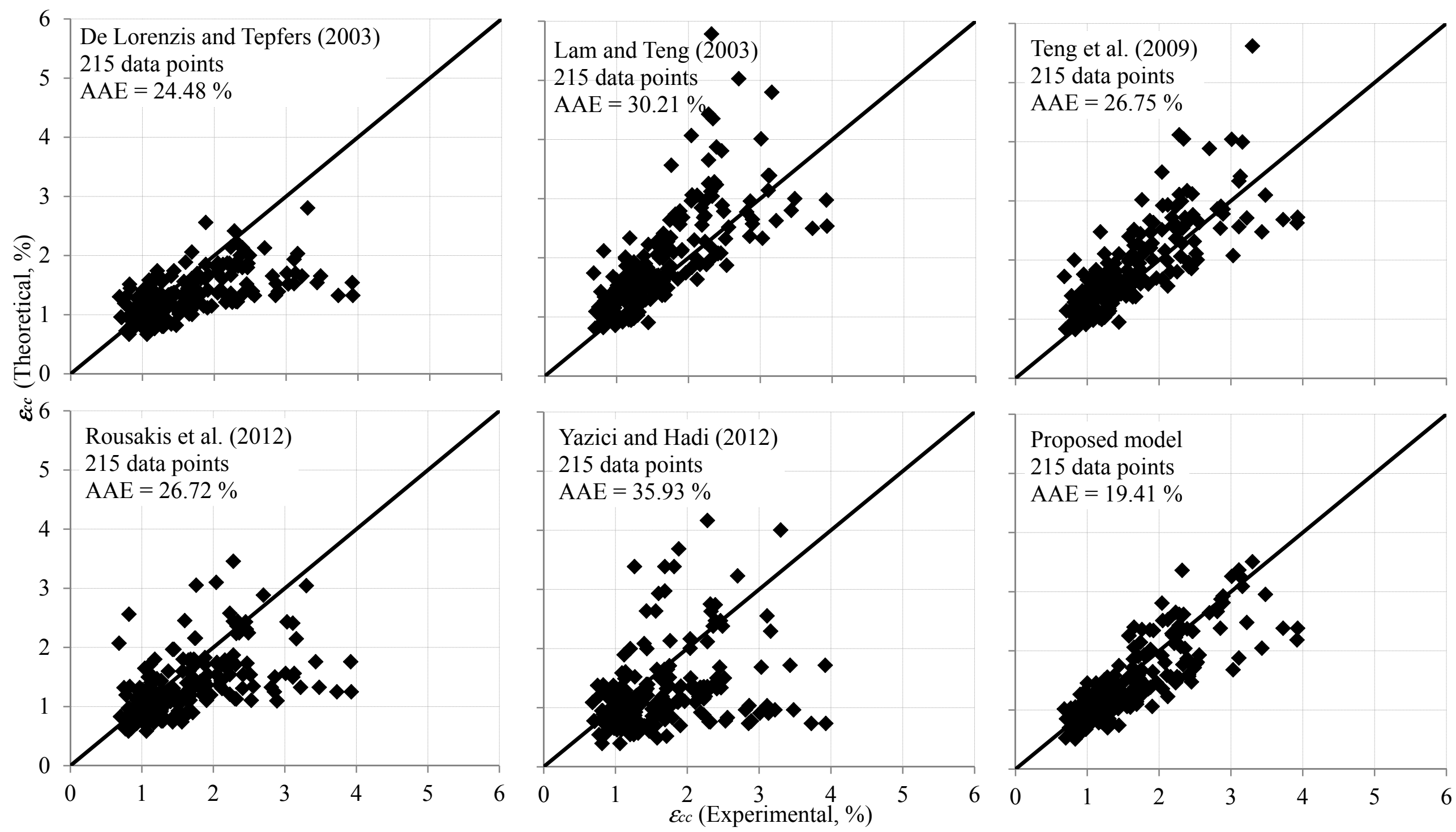


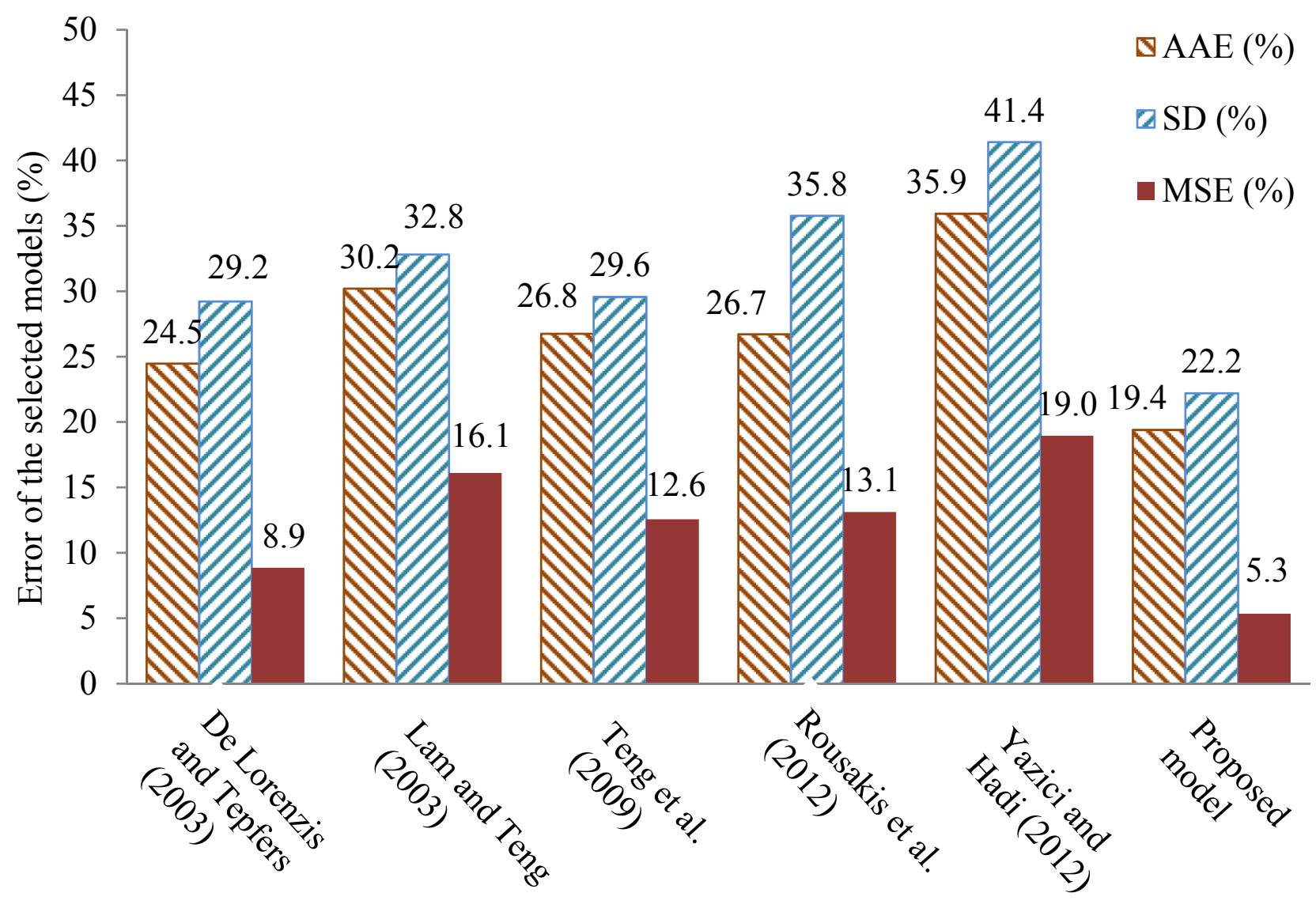

